\title{
Nomenclatural Changes in Epipactis (Orchidaceae) from China
}

\author{
Sing Chi Chen \\ Laboratory of Systematic and Evolutionary Botany, Institute of Botany, Chinese Academy of \\ Sciences, Beijing 100093, China. SCChen@ns.ibcas.ac.cn
}

\section{Guanghua Zhu}

Missouri Botanical Garden, P.O. Box 299, St. Louis, Missouri 63166-0299, U.S.A.

Guanghua.Zhu@mobot.org

ABstract. New rank is proposed for Epipactis humilior (Tang \& Wang) S. C. Chen \& G. Zhu and E. helleborine (L.) Crantz var. tangutica (Schlechter) S. C. Chen \& G. Zhu. Epipactis humilior was formerly treated as a variety of E. mairei Schlechter, but distinctly differs from the latter by having a slender, creeping, elongated rhizome, ovate-lanceolate or lanceolate leaves $2-3 \mathrm{~cm}$ wide and scarcely or slightly scabrous adaxially. Epipactis helleborine var. tangutica is characterized by possessing on the epichile two much larger fleshy calli rather than small semiorbicular warty lamellae seen in E. helleborine.

Key words: China, Epipactis, Orchidaceae.

Epipactis Zinn is an orchid genus of some 20 species distributed mainly in Europe and eastern Asia with a few species extending to North America, Indochina, and Thailand. In China eight species and one variety were recognized recently (Luo, 1999), of which some nomenclatural problems have been discussed (Chen \& Luo, 2002a, 2002b) after a recent visit of the senior author to European herbaria. This is another note, proposing new ranks for two taxa: Epipactis humilior and E. helleborine var. tangutica.

Epipactis humilior (Tang \& Wang) S. C. Chen \& G. Zhu, stat. nov. Basionym: Epipactis mairei Schlechter var. humilior Tang \& Wang, Acta Phytotax. Sin. 1: 67. 1951. TYPE: China. Sikang [Sichuan]: without precise locality, S. M. Liu 1107 (holotype, PE).

This is a rare taxon that was earlier treated as a variety of Epipactis mairei in volume 17 of the Flora Reipublicae Popularis Sinicae (1999). Epipactis humilior is similar in floral structure to E. mairei, but its flowers are slightly smaller, with lateral sepals 13-17 mm long (vs. 15-20 mm long in $E$. mairei). Further, Epipactis mairei is a widespread species characterized by having a rather thick and short rhizome and usually elliptic to elliptic-ovate leaves up to $3-8 \mathrm{~cm}$ wide and strongly scabrous adaxially. Epipactis humilior is quite distinctive by possessing a slender, creeping, elongated rhizome and ovate-lanceolate to lanceolate leaves $2-3 \mathrm{~cm}$ wide and scarcely or slightly scabrous adaxially. These features are of significance in the interspecific classification of Epipactis (Chen \& Luo, 2002a). For example, E. helleborine, E. papillosa Franchet \& Savatier, and E. mairei are never found possessing slender creeping rhizomes, while E. royleana Lindley, E. gigantea Douglas ex Hooker, and E. veratrifolia Boissier \& Hohenacker always have slender, creeping, elongated rhizomes.

The vegetative characters of Epipactis humilior are similar to those of $E$. veratrifolia Boissier \& Hohenacker (syn. E. comsimilis Wallich ex Hooker f., 1890, non D. Don, 1825, see Chen \& Luo, $2000 \mathrm{~b})$, but the floral structure is quite different. The hypochile of the lip in E. veratrifolia is broadly grooved, without side lobes, conspicuously narrower than the epichile, and lacking lamellae adaxially, whereas in E. humilior it has erect side lobes, conspicuously broader than the epichile, and with 3 crisped lamellae on the disk. It therefore seems more reasonable to treat it as a separate species than a variety.

Epipactis helleborine (L.) Crantz var. tangutica (Schlechter) S. C. Chen \& G. Zhu, stat. nov. Basionym: Epipactis tangutica Schlechter, Feddes Repert. Spec. Nov. Regni Veg. Beih. 4: 149. 1919. TYPE: China. Kansu [Gansu]: Tangut, N. M. Przewalski s.n. (syntypes, B [presumed destroyed], K, LE not seen, P).

Epipactis tangutica was reduced to a synonym of E. helleborine in FRPS vol. 17 (Luo, 1999), though it was recognized by Tang and Wang as a distinct species in their manuscript (unpublished, preparing for the orchid flora of China). A close examination of the type specimens at $\mathrm{K}$ and $\mathrm{P}$ revealed 
that E. tangutica is distinguishable by its epichile on which two basal appendages are large fleshy calli rather than two smaller semiorbicular warty lamellae as seen in E. helleborine. Considering that the appendages on the epichile of the floral lip are usually variable in some species of this genus, and phytogeographically this entity is sympatric with $E$. helleborine, it seems reasonable to suggest that $E$. tangutica be recognized at the varietal rank within E. helleborine.

Acknowledgments. The authors thank Ph. Morat and T. Deroin (P) and S. J. Owens and P. Cribb (K) for their kind help and permission to study their collections.

\section{Literature Cited}

Chen, S. C. \& Y. B. Luo. 2002a. Critical notes on some species of Epipactis (Orchidaceae). Acta Phytotax. Sin. 40: 141-146. $\&-2002 \mathrm{~b}$. The identity of a specific name of Epipactis. Acta Phytotax. Sin. 40: 465-469.

Luo, Y. B. 1999. Epipactis. In Flora Reipublicae Popularis Sinicae, Vol. 17: 86-93. Science Press, Beijing. 


\section{$2 \mathrm{BHL}$ Biodiversity Heritage Library}

Chen, Xinqi and Zhu, Guanghua. 2003. "Nomenclatural Changes in Epipactis (Orchidaceae) from China." Novon a journal of botanical nomenclature from the Missouri Botanical Garden 13, 423-424. https://doi.org/10.2307/3393373.

View This Item Online: https://www.biodiversitylibrary.org/item/14673

DOI: https://doi.org/10.2307/3393373

Permalink: https://www.biodiversitylibrary.org/partpdf/122158

\section{Holding Institution}

Missouri Botanical Garden, Peter H. Raven Library

\section{Sponsored by}

Missouri Botanical Garden

\section{Copyright \& Reuse}

Copyright Status: In copyright. Digitized with the permission of the rights holder.

License: http://creativecommons.org/licenses/by-nc-sa/3.0/

Rights: https://biodiversitylibrary.org/permissions

This document was created from content at the Biodiversity Heritage Library, the world's largest open access digital library for biodiversity literature and archives. Visit BHL at https://www.biodiversitylibrary.org. 